\title{
Stoichiometry in Context: Inquiry-Guided Problems of Chemistry for Encouraging Critical Thinking in Engineering Students
}

\author{
http://dx.doi.org/10.3991/ijep.v3i1.2313 \\ Gabriel Pinto ${ }^{1}$ and María Luisa Prolongo ${ }^{2}$ \\ ${ }^{1}$ Universidad Politécnica de Madrid, Madrid, Spain \\ 2 I.E.S. Manuel Romero, Villanueva de la Concepción, Málaga, Spain
}

\begin{abstract}
This paper focuses on examples of educational tools concerning the learning of chemistry for engineering students through different daily life cases. These tools were developed during the past few years for enhancing the active role of students. They refer to cases about mineral water, medicaments, dentifrices and informative panels about solar power, where an adequate quantitative treatment through stoichiometry calculations allows the interpretation of data and values announced by manufacturers. These cases were developed in the context of an inquiry-guided instruction model. By bringing tangible chemistry examples into the classroom we provide an opportunity for engineering students to apply this science to familiar products in hopes that they will appreciate chemistry more, will be motivated to study concepts in greater detail, and will connect the relevance of chemistry to everyday life.
\end{abstract}

Index Terms-Chemistry for engineering students; critical thinking; consumer chemistry; inquiry-guided learning.

\section{INTRODUCTION}

There are many things that can be done to improve the traditional teaching strategies in general chemistry as in other subjects for undergraduate engineering students, for example:

- Redesign the contents by using interesting examples related to real life. Examples based on everyday life should be used as often as possible. This is one of the best ways to promote the interest of learners, because it helps to increase the relevance of chemistry through the authentic application of chemistry concepts that include social, technological, environmental and economical applications. In order to motivate students, it is particularly important to relate the material to the students' personal experience $[1,2]$. This is due to the fact that students learn best when they perceive a need to know the material being taught.

- Using contemporary teaching approaches. Using adequately different theories about teaching and learning has its advantages, because it is important to select the proper instructional strategy for each specific learning outcome. According to Rüütmann and Kipper [3], knowledge of a variety of instructional strategies and flexibility to change them within and among lessons are two great assets a teacher can have.

Often it is suggested to start a lecture with realistic complex problems, let students what they know and what they need to find out, and then guide them in finding it out by providing a combination of resources and guidance on performing library and Internet research [3]. This kind of inductive teaching may be carried out through a good number of useful strategies and variations, including problem-based learning (by means of challenging tasks for students), project-based learning, case studies, inquiryguided learning, interdisciplinary approaches, cooperative participation, and discovery learning $[4,5]$. Based on the principle that teaching methods are more effective if they are diverse and complementary, the challenge for contemporary teaching is to establish a student centered educative model.

In the last few years we have developed a program intended to help chemistry teachers include connections between students' everyday experience and chemical principles taught in the classroom [6]. The idea is that students have a greater appreciation of the principles of chemistry if they can see the relevance to their own lives. This idea of using a familiar context with chemistry is common but not found usually in textbooks. Furthermore, it is especially important for engineering students, because often they do not feel that general chemistry, usually coursed during the first year of studies, is relevant to the world and different fields of engineering.

Real-world applications (apart from lectures and laboratory work) serve to favor students-centered approaches. By the other hand, the development of context-based exercises is useful for the education of students as consumers, citizens and future informed decision makers. Also, discussing these kinds of examples may encourage students to explore topics in more depth.

In this paper we summarize several works we have developed related to context-based problems and exercises. Although these activities were developed for first-year engineering students, they can be adapted to previous and other educative levels. Activities were worked by groups of three students as homework. Thus, only a short class time was needed for the introduction of the activities and for the final class discussion. There are other possibilities to use the activities with the students. For example, the teacher can ask the questions, followed by a class discussion or students can be divided into groups and to work on guided questions.

We have used these activities in the context of an inquiry-guided instruction (IGI). This methodology adopts a structured approach where student learning is promoted through the use of questions meant to initiate the curiosity of the students to get them started on finding answers to 
their own questions [7, 8]. Usually it relies on group work where students collectively think, reflect, and provide ways by which to solve a problem. The instructor facilitates these processes rather than informing students what needs to be done next. Instructors may choose other methodology, such as problem-based learning (PBL) that better fits their pedagogical goals or teaching styles for solving this kind of exercises.

Important characteristics of these exercises are that students must to work over data mining for solving the problems (sometimes they are open-ended) and that numerical results change (in the range of the same order of magnitude) for different groups of students (decreasing the possibility of cheating).

The design of these activities fulfills the common elements with what Duch identifies as practical criteria for a "good" problem [9]:

- "hooking" the student to spark interest and motivation preferably within a real-life context,

- requiring reflection as students recognize and explain how to proceed, discerning which information is relevant and necessary at each stage of the solving process, and

- relying on group thinking rather than dissecting tasks among group members.

The stoichiometry is the branch of chemistry that deals with the relative quantities of reactants and products [10]. The composition stoichiometry describes the quantitative (mass) relationship among elements and compounds. Stoichiometry is a core nucleus in introductory chemistry. Nevertheless, the traditional way to introduce it is through activities very bored, out of context and consisting of repetitive calculations.

Here are several motivating exercises pertaining to the study of stoichiometry about common products, with a practical and contextual approach.

Apart from an introduction to mass balances and to other important chemistry topics, engineering students must appreciate that stoichiometry is an important topic to understand different aspects over common substances, from mineral waters to dentifrices or medicaments, and over generation of energy, as shown in this paper.

In addition, in general chemistry classes and in other subjects, engineering students are taught that numerical rounding must be done at the end of calculations and that the accuracy of given data must also be considered. These activities could be used to discuss the use of significant figures and precision in results.

\section{Suggested Problems}

In the following paragraphs we include a set of questions, as examples, as they were proposed to students. Questions cover various topics of general chemistry (mainly stoichiometry, as indicated before) that are related to common substances and consumer information about energy. We consider these questions as a starting point: the reader is encouraged to develop additional questions that will encourage students to apply chemical concepts.

\section{A. Problem 1: about the composition of mineral waters}

In this activity you will examine the chemical composition of bottled waters to study and determine what are the total dissolved solids, TDS, present in your bottle. You will apply the law of conservation of mass and use stoichiometry to determine if the label information is accurate.

1. Obtain a label of bottled water from your instructor.

2. Visit a web link with information about mineral waters [11] and choose a product that is similar to the one whose label was provided. Make sure the label contains the TDS (or dry residue), and bicarbonate information among other ions.

3. Evaluate how the TDS is measured.

With the information answer the following questions:

1. Determine the total concentration in $\mathrm{mg} / \mathrm{L}$ of cations, anions, and silica. Does it match the concentration of TDS?

2. From the contents, can you suggest a reason for the discrepancy (if any) found in the previous question?

3. Discuss with your fellow students and inform the instructor about your explanations.

4. Which ingredient you think will decompose easily at $180^{\circ} \mathrm{C}$ giving gaseous products? Write balanced chemical equations for those ingredients that could decompose at high temperatures.

5. Calculate again the total concentration in $\mathrm{mg} / \mathrm{L}$ of ions and silica, this time taking into account the loss of gases during the decomposition of the bicarbonate ion. How does this number compare to the reported TDS?

6. Compare the concentration of positive versus negative charges. Do you need to convert units of $\mathrm{mg} / \mathrm{L}$ to $\mathrm{mmol} / \mathrm{L}$ to make this comparison? Do they match? What does this result imply?

\section{B. Problem 2: about the composition of toothpaste}

The information given on dentifrice packages indicates that a quantity of fluorine compound is equivalent to a certain quantity of fluoride ion, as indicated in brackets. Confirm the values listed from the stoichiometry calculations:

Dentifrice A: $0.325 \%$ sodium fluoride (1477 $\mathrm{ppm} \mathrm{F}^{-}$).

Dentifrice B: $0.32 \%$ sodium fluoride (1450 $\mathrm{ppm} \mathrm{F}^{-}$).

Dentifrice C: $0.177 \%$ sodium fluoride (805 ppm F $\mathrm{F}^{-}$.

Dentifrice D: $1.9231 \%$ sodium monofluorophosphate (2500 ppm $\mathrm{F}^{-}$).

Dentifrice E: $1.0230 \%$ sodium monofluorophosphate and $0.0335 \%$ sodium fluoride (1500 $\left.\mathrm{ppm} \mathrm{F}^{-}\right)$.

\section{Problem 3: about the stoichiometry of an iron medicament and consumer chemistry}

The current information leaflet for a medicine indicates that each tablet contains $256.30 \mathrm{mg}$ of ferrous sulfate sesquihydrate, equal to $80 \mathrm{mg}$ of iron(II) ion. In a previous version of the leaflet, the same manufacturer indicated that the amount of this salt per tablet is $270 \mathrm{mg}$ and that it is also equivalent to $80 \mathrm{mg}$ of iron(II) ion. According to stoichiometric considerations, which of the two leaflets gives the correct amount?

\section{Problem 4: about the composition of calcium medicaments}

The information leaflet for several medicines indicate that a quantity of different compounds is equivalent to a 
certain quantity of calcium ion, as indicated in brackets. Check by stoichiometry the values of equivalences given: $\left.\mathrm{Ca}^{2+}\right)$

Medicine A: $1250 \mathrm{mg}$ calcium carbonate $(500 \mathrm{mg}$

Medicine B: $1260 \mathrm{mg}$ calcium carbonate (500 mg $\mathrm{Ca}^{2+}$.

Medicine C: $2500 \mathrm{mg}$ calcium carbonate $\left(1000 \mathrm{mg} \mathrm{Ca}^{2+}\right.$ or $25 \mathrm{mmol} \mathrm{Ca}{ }^{2+}$ ).

Medicine D: $3.3 \mathrm{mg}$ calcium phosphate $\left(1.2 \mathrm{~g} \mathrm{Ca}^{2+}\right)$.

Medicine E: A spoonful $(=15 \mathrm{~mL})$ of solution with $1671 \mathrm{mg}$ calcium phosphate per $100 \mathrm{~mL}\left(100 \mathrm{mg} \mathrm{Ca}^{2+}\right)$.

\section{E. Problem 5: about the emissions of $\mathrm{CO}_{2}$ averted by the use of solar power}

Data about energy consumption can usually be found on information panels at different public places, where part of the energy is supplied by solar cells. Often these data are presented in terms of solar power currently delivered $(\mathrm{kW})$, total solar energy supplied to the network $(\mathrm{kWh})$, and avoided emissions $\left(\mathrm{kg}\right.$ of $\left.\mathrm{CO}_{2}\right)$. As an example, in Figure 1 the photography of a panel with these data is shown. Explain quantitatively the relationship between total solar energy supplied ( $\mathrm{kWh}$ ), and avoided emissions $\left(\mathrm{kg}\right.$ of $\mathrm{CO}_{2}$ ) shown in it.

\section{ANSWERS AND COMMENTS FOR THE PROBLEMS}

\section{A. Answer to problem 1}

Mineral waters contain, as suggests the name, various minerals (inorganic compounds) as it is indicated in the label of bottles. Waters are heated at $180{ }^{\circ} \mathrm{C}$ during the determination of the TDS and at this temperature bicarbonate decomposes as represented by the equation:

$$
2 \mathrm{HCO}_{3}{ }_{(\mathrm{aq})}^{-} \rightarrow \mathrm{CO}_{3}{ }^{2-}{ }_{(\mathrm{aq})}+\mathrm{CO}_{2(\mathrm{~g})}+\mathrm{H}_{2} \mathrm{O}_{(\mathrm{g})}
$$

which implies a loss of gases that needs to be taken into account when comparing reported data. Instructors should be aware, in order to facilitate this activity, that ingredient labels must contain information on the TDS (or dry residue), bicarbonate, and silica concentrations.

An example is calculated using the brand Frasassi (Italy) as shown in Table 1 . The sum of ions and silica from data is $480.7 \mathrm{mg} / \mathrm{L}$. Considering the decomposition of bicarbonate, it is clear that for every mmol of $\mathrm{HCO}_{3}^{-}$, $18.02 / 2 \mathrm{mg}$ of water vapor and $44.01 / 2 \mathrm{mg}$ of $\mathrm{CO}_{2}$ gas are produced.

Therefore, the sum of ions and silica minus the sum of gaseous components "lost" during the chemical analysis gives: $480.7 \mathrm{mg} / \mathrm{L}-152.0 \mathrm{mg} / \mathrm{L}=328.7 \mathrm{mg} / \mathrm{L}$. This value is close to the TDS amount reported, with a minor difference (only around $10 \mathrm{mg} / \mathrm{L}$ ), probably owing to the presence of minority substances. The sum of positive charges is $6.299 \mathrm{mmol} / \mathrm{L}$ and the sum of negative charges is $5.963 \mathrm{mmol} / \mathrm{L}$. There is a slight excess ( 5 per cent) of positive charges, owing to other minority components and to uncertainties of analytical measures.

This problem may serve to explore other topics such as water hardness, characterization of beverages and chemical analysis. The activity may be used to suggest ideas for additional experimentation [12].

\section{B. Answer to problem 2}

Really, the information indicated on dentifrice packages is given usually as the equivalence between fluorine com-

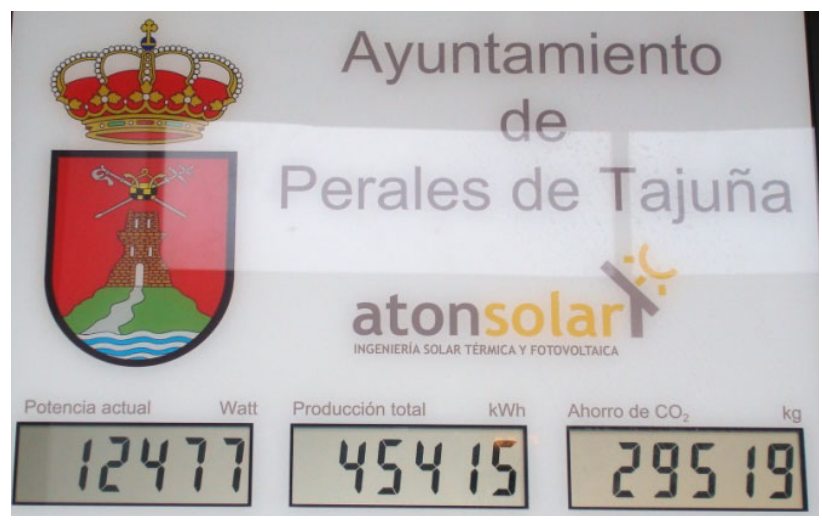

Figure 1. Information panel at a sport centre in a village of Spain, showing the $\mathrm{CO}_{2}$ emissions (29519 $\mathrm{kg} \mathrm{CO}_{2}$ ) avoided by using solar power rather than carbon-based fuels for a power source. A total production of energy of $45415 \mathrm{kWh}$ is shown.

TABLE I.

CHEMICAL COMPOSITION OF AN EXAMPLE OF MINERAL WATER (FRASASSI, ITALY) AND CALCULATIONS OF CONTENT AND CHARGES.

\begin{tabular}{|l|l|l|l|}
\hline & $\begin{array}{l}\text { Content* } \\
(\mathbf{m g} / \mathbf{L})\end{array}$ & $\begin{array}{l}\text { Content } \\
(\mathbf{m m o l} / \mathbf{L})\end{array}$ & $\begin{array}{l}\text { Charge } \\
(\mathbf{m m o l} / \mathbf{L})\end{array}$ \\
\hline $\mathrm{Ca}^{2+}$ & 99.5 & 2.483 & 4.966 \\
\hline $\mathrm{Mg}^{2+}$ & 4.3 & 0.177 & 0.354 \\
\hline $\mathrm{Sr}^{2+}$ & 2.7 & 0.031 & 0.062 \\
\hline $\mathrm{Na}^{+}$ & 19.9 & 0.866 & 0.866 \\
\hline $\mathrm{K}^{+}$ & 2.0 & 0.051 & 0.051 \\
\hline $\mathrm{HCO}_{3}{ }^{-}$ & 299.0 & 4.900 & 4.900 \\
\hline $\mathrm{Cl}^{-}$ & 19.4 & 0.547 & 0.547 \\
\hline $\mathrm{SO}_{4}^{2-}$ & 24.8 & 0.258 & 0.516 \\
\hline $\mathrm{SiO}_{2}$ & 9.1 & \multicolumn{2}{|l}{} \\
\cline { 1 - 2 } $\mathrm{TDS}^{2-}$ & 339 & & \\
\cline { 1 - 2 } & &
\end{tabular}

* Data provided by the manufacturer at the label of the bottle.

pounds and a quantity of "elemental fluorine". Never theless, we offer data for equivalence in $\mathrm{F}^{-}$ion to facilitate the understanding of the problem to students. In the dentifrice A, taken as an example, the stoichiometric calculations involve the expression:

$$
\begin{aligned}
& \frac{0.325 \mathrm{~g} \mathrm{NaF}}{100 \mathrm{~g} \text { dentifrice } \cdot 10^{-3} \frac{\mathrm{kg}}{\mathrm{g}}} \times \frac{1 \mathrm{~mol} \mathrm{NaF}}{41.99 \mathrm{~g}} \times \frac{1 \mathrm{~mol} \mathrm{~F}^{-}}{1 \mathrm{~mol} \mathrm{NaF}} \times \\
& \times \frac{19.00 \mathrm{~g} \mathrm{~F}^{-}}{\mathrm{mol} \mathrm{F}^{-}} \times \frac{10^{3} \mathrm{mg}}{1 \mathrm{~g}}=1471 \mathrm{mg} \mathrm{F}^{-} / \mathrm{kg} \text { dentifrice }
\end{aligned}
$$

Equivalence of $\mathrm{F}$ element for dentifrices $\mathrm{B}$ and $\mathrm{C}$ can be calculated analogously. The calculation for dentifrice $\mathrm{E}$ requires the molar mass of $\mathrm{Na}_{2} \mathrm{PO}_{3} \mathrm{~F}(143.95 \mathrm{~g} \cdot \mathrm{mol})$. For dentifrice I both molar masses must be taken into account. Taking into account the number of significant figures given by manufacturers, the corresponding equivalences in F element are: B (1448 ppm), C (801 ppm), D (2538.3 ppm) and $E(1502 \mathrm{ppm})$. Calculated values are close to those indicated by the manufacturers. More information about fluorine compounds and dental health can be consulted in [13]. For information about the composition of toothpastes there are different sources such as the work by Reynold [14]. 


\section{Answer to problem 3}

Iron is essential for the production of hemoglobin, the red oxygen carrying pigment in red blood cells. Iron(II) sulfate sesquihydrate is used in pharmaceutical products for iron-deficiency anemia. The molar mass of $\mathrm{FeSO}_{4} \cdot 1.5 \mathrm{H}_{2} \mathrm{O}$ is $178.93 \mathrm{~g} / \mathrm{mol}$. By considering the current leaflet, the equivalent of iron present in each tablet is $80 \mathrm{mg} \mathrm{Fe}{ }^{2+}$, as shown at the end of this paragraph. So the current leaflet's claim is correct. For completeness, following the same stoichiometric procedure, the value of $270 \mathrm{mg}$ of salt, given in the other instructions, corresponds to $84.3 \mathrm{mg}$ of $\mathrm{Fe}^{2+}$.

$$
\begin{gathered}
\frac{0.25630 \mathrm{~g} \mathrm{salt}}{178.93 \mathrm{~g} / \mathrm{mol} \mathrm{salt}} \times \frac{1 \mathrm{~mol} \mathrm{Fe} \mathrm{e}^{2+}}{1 \mathrm{~mol} \mathrm{salt}} \times \frac{55.85 \mathrm{~g} \mathrm{Fe}^{2+}}{1 \mathrm{~mol} \mathrm{Fe}^{2+}} \times \\
\times \frac{10^{3} \mathrm{mg}}{1 \mathrm{~g}}=80.00 \mathrm{mg} \mathrm{Fe}^{2+}
\end{gathered}
$$

This problem is an example especially indicated to underline to students the importance of general chemistry not only for an engineering students but general public, as consumer. The elucidation of the correct information provided by the manufacturer is a good opportunity to develop a critical thinking by students, one of the goals of this kind of educative tools.

\section{Answer to problem 4}

Analogously to the case $\mathrm{B}$, the information indicated on calcium medicaments is given usually as the equivalence between calcium compounds and a quantity of "elemental calcium". As in the case B, we offer data for equivalence in $\mathrm{Ca}^{2+}$ ion to facilitate the understanding of the problem to students.

Calcium makes up about $2.0 \%$ of the total body weight. In addition to its major function in building and maintaining bones and teeth, it is also necessary for important biological contributions including nerve transmission and regulation of the heart beat. A calcium deficiency contributes to the development of osteoporosis. The best sources of calcium are milk, fish (salmon and sardines with bones), and dark green vegetables (broccoli, collard greens...).

There are different calcium supplements sources for use in dietary supplements: inorganic salts, such as calcium carbonate or phosphate, and organic salts such as calcium lactate or gluconate.

In the medicine $\mathrm{A}$, taken as an example, the stoichiometric calculations involve the expression:

$$
\begin{aligned}
& \frac{1.250 \mathrm{~g} \mathrm{CaCO}_{3}}{100.1 \mathrm{~g} / \mathrm{mol} \mathrm{CaCO}_{3}} \times \frac{1 \mathrm{~mol} \mathrm{Ca}^{2+}}{1 \mathrm{~mol} \mathrm{CaCO}_{3}} \times \\
& \times \frac{40.08 \cdot 10^{3} \mathrm{mg} \mathrm{Ca}^{2+}}{\mathrm{mol} \mathrm{Ca}^{2+}}=500.5 \mathrm{mg} \mathrm{Ca}^{2+}
\end{aligned}
$$

Equivalence of $\mathrm{Ca}^{2+}$ ion for medicaments $\mathrm{B}$ and $\mathrm{C}$ can be calculated analogously. The stoichiometric calculations for medicaments $\mathrm{D}$ and $\mathrm{E}$ requires the molar mass of $\mathrm{Ca}_{3}\left(\mathrm{PO}_{4}\right)_{2}(310.3 \mathrm{~g} / \mathrm{mol})$. The corresponding equivalences in $\mathrm{Ca}^{2+}$ ion are: $\mathrm{B}(504.5 \mathrm{mg}), \mathrm{C}(1001 \mathrm{mg}$ or $25 \mathrm{mmol}), \mathrm{D}$ $(1.28 \mathrm{mg})$ and $\mathrm{E}(97 \mathrm{mg})$.
In most cases the calculated values are close to the indicated by the manufacturers, but there are significant differences that range from $-3 \%$ to $+7 \%$. Other examples about calcium medicines stoichiometry and about other chemistry topics related to them were studied before [15].

\section{E. Answer to problem 5}

In a coal thermal power plant, taken as an example of conventional source of energy, the energy is obtained from combustion of coal. Heat from combustion is used to boil water, generating the steam to power steam engines and turbines that are used to make electricity. $\mathrm{CO}_{2}$ gas is a by-product of burning coal to make electricity.

The combustion energy of graphite (taken as a simplification of coal) is:

$$
\mathrm{C}_{\text {(graphite) }}+\mathrm{O}_{2(\mathrm{~g})} \rightarrow \mathrm{CO}_{2(\mathrm{~g})} \quad \Delta \mathrm{H}^{\mathrm{o}}=-393.5 \mathrm{~kJ}
$$

The equivalence between total solar energy supplied and avoided emissions, taking into account the molar mass of $\mathrm{CO}_{2}$ and data in Figure 1, is given by:

$$
\begin{gathered}
\frac{45415 \frac{\mathrm{kJ}}{\mathrm{s}} \cdot 3600 \mathrm{~s}}{29519 \mathrm{~kg} \mathrm{CO} 2 / 0.044 \mathrm{~kg} / \mathrm{mol} \mathrm{CO}} \mathrm{CO}_{2} \\
=243.7 \mathrm{~kJ} / \mathrm{mol} \mathrm{CO}
\end{gathered}
$$

This value is of the order of magnitude of the equivalence of energy supplied per mole of $\mathrm{CO}_{2}$. According to the result, about $62 \%$ of the thermal coal is converted to electricity (the energy efficiency). This is one approach; apart from coal, other fossil fuels such as natural gas and oil products can be used to make electricity in thermal power plants. Students can use different values as shown in the information panels they encounter.

This example may encourage students to explore other topics, such as the effects of global warming, clean energy equivalencies, and renewable resources of energy. Other example, with potential interest for engineering students to illustrate chemical principles, related analogous topics through questions about the relationship between vehicle fuel consumption and $\mathrm{CO}_{2}$ emissions and it was published before [16].

\section{CONCLUSIONS}

With the aim of supplementing the traditional content of introductory chemistry for engineering students, with training in critical and creative thinking, we suggested a few examples of solving open-ended problems. These examples clearly link stoichiometry chemistry principles to real life. Other topics, such as consumer chemistry, chemical formulation, chemistry and health, production of energy, and rounding off in calculations were included. Students have expressed keen interest in this type of "tangible" chemistry where concrete examples put textbook chemistry in context and help them to better understand chemistry topics.

In line with what was suggested in other papers published in this Journal, besides offering students the opportunity to develop critical thinking [17], suggested activities try for improving their motivation [18]. 
By bringing tangible chemistry examples we provide an opportunity for students to apply chemistry to familiar products in hopes that they will be motivated to study concepts in greater detail, and will connect the relevance of chemistry to everyday lives.

First-year undergraduate engineering students appreciated the question-answer approach and were motivated and interested. They liked the activities and most of them gained an appreciation for the necessity to study chemistry as an introductory science for their specializations.

As can be observed the proposed examples put emphasis not only in chemistry topics or social issues; also other skills, such as searching of data or elaboration of tables with scientific data, and so on, are developed. For example, students need to search for data such as atomic masses, enthalpies, composition of mineral waters..., to solve the problems.

The implications and environment issues related to proposed chemistry studies makes this science more relevant, real-life reflection and practical to students.

According to our experience this kind of instructional tools is an effective way to help improve the students' engagement, motivation and interest in chemistry.

\section{ACKNOWLEDGMENT}

We would like to gratefully recognize the support provided by the Universidad Politécnica de Madrid, under the project "Active agents and catalysts: new educative tools for chemistry".

\section{REFERENCES}

[1] A. Melezinek, Ingenieurpädagogik. Praxis der Vermittlung technischen Wissens, $4^{\text {th }}$ ed., Wien/New York: Springer Verlag, 1999.

[2] D.C. Orlich, R.J. Harder, R.C. Callaham, M.S. Trevisan, and A.H. Brown, Teaching strategies - A guide to effective instruction, $9^{\text {th }}$ ed., Boston, MA: Wadsworth Lengage Learning, 2010.

[3] T. Rüütmann, and H. Kipper, Teaching strategies for direct and indirect instruction in teaching engineering, Int. J. Engin. Pedag., vol. 1(3), pp. 37-44, 2011

[4] G.D. Borich, Effective teaching methods, research-based practice, $7^{\text {th }}$ ed., New York: Pearson, 2011.

[5] P.R. Burden, and D.M. Byrd, Methods for effective teaching: meeting the needs of all students, $6^{\text {th }}$ ed., New York: Pearson, 2012.

[6] Grupo de Didáctica de la Química de la UPM. Didáctica de la química y vida cotidiana (Didactics of chemistry and everyday life). Retrieved from: http://quim.iqi.etsii.upm.es/vidacotidiana/ Inicio.htm

[7] L. Martin-Hansen, Defining inquiry, Sci. Teacher, vol. 69(2), 34 37, 2002.

[8] M.T. Oliver-Hoyo, M. Anderson, and D.D. Allen, Implementing inquiry-guided instruction: practical issues, J. College Sci. Teach., vol. 33(6), pp. 20-24, 2004.
[9] B. Duch, Problems: A key factor in PBL. Retrieved from: http://www.udel.edu/pbl/cte/spr96-phys.html.

[10] See for example: (a) P. Kelter, M. Mosher, and A. Scott, Chemistry: the practical science, Boston/New York: Houghton Mifflin Company, 2008, p. 108. (b) Chemteam: a tutorial for High School chemistry. Retrieved from: http://www.chemteam.info/ Stoichiometry/Stoichiometry.html

[11] Mineral waters of the world (2005). Waters listed by country. Retrieved from: http://www.mineralwaters.org/

[12] G. Pinto, and M.T. Oliver-Hoyo, What's in your bottled water? Look at the label! Chem. Educator, vol. 13, pp. 341-343, 2008.

[13] G. Pinto, Fluorine compounds and dental health: applications of general chemistry topics, J. Chem. Educ., vol. 86, pp. 185-187, 2009. http://dx.doi.org/10.1021/ed086p185

[14] E.C. Reynold, Contents of toothpaste-safety implications. Australian Prescriber, vol. 17, pp. 49-51, 1994. Retrieved from: http://www.australianprescriber.com/magazine/17/2/49/51/

[15] G. Pinto, Stoichiometry of calcium medicines, J. Chem. Educ., vol. $82, \quad$ pp. $1509-1512,2005$. http://dx.doi.org/10.1021/ $\underline{\text { ed082p1509 }}$

[16] M.T. Oliver-Hoyo, and G. Pinto, Using the relationship between vehicle fuel consumption and $\mathrm{CO}_{2}$ emissions to illustrate chemical principles, J. Chem. Educ., vol. 85, pp. 218-220, 2008. http://dx.doi.org/10.1021/ed085p218

[17] W.W. Goh, Can Wiki be used to facilitate critical thinking?: A qualitative approach, Int. J. Engin. Pedag., vol. 2(4), pp. 18-23, 2012.

[18] A. Gero, Improving intrinsic motivation among sophomore electrical engineering students by an introductory project, Int. $J$. Engin. Pedag., vol. 2(4), pp. 13-17, 2012.

\section{AUTHORS}

Gabriel Pinto is a professor at the Universidad Politécnica de Madrid, where he has taught chemistry for engineers since 27 years. His research has concentrated on properties of polymer and polymer composites, and on the problems of teaching and learning of chemistry and engineering. He has written nine books and one hundred papers about science and engineering education. He is with E.T.S. de Ingenieros Industriales, José Gutiérrez Abascal 2, 28006 Madrid, Spain (e-mail: gabriel.pinto@upm.es).

María Luisa Prolongo studied industrial chemistry at the Universidad de Málaga, Spain, and has taught secondary-school science for around 18 years. She is interested in students-centered learning methodologies. She has involved in many school projects on chemistry and physics education and she has won several awards in calls for educational innovation. She is with the I.E.S. Manuel Romero, Villanueva de la Concepción, 29230 Málaga, Spain (e-mail: marisaprolongo@hotmail.com).

This work was supported in part by Universidad Politécnica de Madrid. Received 18 October 2012. Published as resubmitted by the authors on 18 December 2012. 